\title{
Minangkabau Oral Tradition Performer and Social Media Usage
}

\author{
E Meigalia $^{1}$, Y S Putra ${ }^{2}$ \\ Universitas Andalas, Padang \\ \{ekameigalia@fib.unand.ac.id¹, yerri@hum.unand.ac.id²\}
}

\begin{abstract}
Speakers of oral tradition are one of the determinants of the continuation of the tradition in the community. At present various aspects of people's lives cannot be separated from the internet and social media. Then what about the speakers of the oral tradition? Can they bring oral traditions to exist and be enjoyed by society in this era? For this reason, this paper will explain various forms of social media use by speakers related to the expertise of their oral traditions. The object of research is Minangkabau oral tradition and three speakers on social media Instagram and youtube which have indeed been active and exist on both social media. The research method used is qualitative with data collection techniques in the form of observations on social media and interviews with some speakers of oral traditions. Based on the research, the speakers use social media is not currently aimed to bring oral traditions to be enjoyed by the people who use social media. This means that the presence of the internet, multimedia, and social media technology has not become a means of strengthening and inheriting oral traditions in the Minangkabau.
\end{abstract}

Keywords: Minangkabau, Oral Tradition, Social Media, Speakers, Use, Digital Era

\section{INTRODUCTION}

Minangkabau ethnics administratively inhabit the area of West Sumatra Province. But Minangkabau ethnicity can also be found in various parts of the world because of the tradition of marantau (merantau) which has also been carried out for generations. Besides marantau, Minangkabau people are also famous for their proficiency in speaking. Oral tradition is one of the manifestations of the Minangkabau's proficiency in speaking.

Lots of oral traditions that developed in Minangkabau. One of them is the Pasambahan tradition. Pasambahan is a tradition of expressing respect or telling one purpose with respect to those who are glorified. This notification is compiled in poetic words, full of figurative expressions, wisdom, verses, and sounds rhythmic because of the pattern of sound equations. This tradition was carried out by Minangkabau people in various processions. In a wedding ceremony, start an event, death ceremony, batagak gala, and so on [1].

Adriyetti Amir and her friends have mapped and found at least thirty types of oral traditions spread across various regions. But some of these oral traditions are no longer displayed, such as iriak onjai in the Rao area, Pasaman. This tradition is a tradition of pantun recitations performed by a group of men when they harvest rice. This tradition is no longer performed because the activities of harvesting rice in a row have rarely been done. Amir also 
added in his writing that at this time the younger generation was no longer interested in the tradition [2].

Nowadays people's lives have entered a period referred to by Walter J. Ong [3] as a period of secondary orality. That is when people have known printing (the tradition of writing), telephone, radio, television, and various electronic technologies. Then since the middle of the last century, society also entered an era known as the digital era by facilitating all forms of human work with the help of the internet, digital technology, and social media [4]. During this time, some oral traditions were lost, not inherited, and no longer functioning in the community. One reason is that there is no longer inheritance from active speakers to the younger generation. Such as the tradition of dendang sampelong (narrative rhyme accompanied by rhythms of wind instruments, sampelong) in Lima Puluh Kota Regency, West Sumatra. from Nagari Talang Maua. In 2019 this is the Islamic age of 78 years. After Islamidar, trad the content of the sample is feared to be lost along with other oral traditions which have already disappeared.

In this regard, the presence of digital technology and social media can be said to be a threat to the sustainability and inheritance of oral traditions in the community. However, Min Xu [5] explained that the technological developments that are present in society today can actually improve the economy and the quality of human life. Of course with new ideas and the use of existing technology. That is, the problem will be lost and no longer inherited oral traditions can be overcome through the use of digital technology.

Based on this, this paper will explain the use of digital and multimedia technology that is developing at this time to preserve and inherit Minangkabau oral traditions. Specifically to be discussed is the use of social media (Instagram, YouTube) which is already very familiar to most people everywhere. Social media, in this case, is considered as a means of conveying ideas, ideas, and communicating between users. Therefore, speakers of oral tradition are members of the community who actually have the potential and opportunity to use social media as a means of sustainability and inheritance of oral traditions.

Several previous studies have shown the use of digital technology in oral traditions in various countries. Among these are Tshering Dorji's research [6] which explains the efforts to save and promote oral traditions from Bhutanese society through the use of digital technology. Then the study of Muhammad Zaffwan Idris and friends [7] concerning various problems and challenges in saving the culture of things that happened in several cases in various countries. Also research by Mohd Izani Zainal Abidin, Aishah Abd Razak [8] and Lopamudra Maitra [9] on the use of digital technology and multimedia as learning tools for children based on oral stories.

\subsection{Research Method}

This research is a qualitative study with social media account data sources from three active speakers of the Minangkabau oral tradition. The three active speakers were chosen based on their activeness on Instagram social media, and YouTube which is currently popular among the younger generation. In this case, the three speakers were recorded as active in the tradition of bagurau, salawat dulang, and tuturan adat (pasambahan, pantun, pituah).

YouTube and Instagram social media, in this case, are not just a means of communication between users. Both of these accounts have also been actively used to make money. A variety of creative content is uploaded by users with the ultimate goal of improving community welfare. This is also in line with government programs to encourage the creative industry sector. Oral tradition is one of the main objects that can be developed to produce creative 
products. The creative industry is intended as a system and economic practice based on knowledge and creativity [10]. Therefore, YouTube and Instagram social media were chosen for this study.

Data collection is done through observation and interview. Observation aims to get an overview of the activities of these speakers on social media. While the interview serves to obtain additional data. Then the data will be presented descriptively.

\subsection{Result and Discussion}

There are various terms to refer to people presenting performances of oral traditions. Albert B. Lord [11] called it the term "guslar", Adriyetti Amir [12] called it "the performer", and Pudentia [13] called "speaker". In this case, the author uses the term "speaker" which specifically refers to people who speak oral texts in one show of oral tradition. In a more specific scope, speakers of this oral tradition have different titles according to the oral tradition genres that are displayed. For example, speakers of the pasambahan tradition are called "tukang sambah", "tukang salawat" for the tradition of salawat dulang, and "tukang dendang" for the bagurau tradition.

Speakers of this oral tradition inherit the expertise to speak through several stages. Lord [11] describes these stages in three parts. The first stage is when prospective speakers who are used to watching and like a genre of oral tradition begin to have an interest and desire to learn. At this stage young speakers actually, recognize and have memories of some texts that they often hear. The second stage is to meet and ask senior speakers directly to become teachers or reduce their skills. Senior speakers will usually give some conditions and then provide some texts to memorize. Young speakers will be trained to have sufficient mastery of the oral traditions they are learning. The final stage is when young speakers are brought in by senior speakers to appear in support or replace in several sessions. It is at this final stage that the skills of young speakers will continue to be honed so that eventually they can become independent performers.

The stages of inheritance as stated by Lord above also occur in oral traditions in Minangkabau. Such research has been conducted by the researchers themselves towards the tradition of salawat dulang [14]. Salawat dulang is one of the few oral traditions in Minangkabau that still survives. The speakers are still quite a lot, even from the younger generation. In contrast to other oral traditions, the speaker has an average age of 40 years or over 50 years. There is even an oral tradition where the speaker lives only one person and his age is over 70 years. Here it can be seen that the intergenerational inheritance process in some oral traditions still occurs, and some of it no longer exists.

Based on previous studies, speakers of senior oral traditions have been able to survive and adapt to the times and also technology. Especially radio and television. Speakers of the oral tradition in Minangkabau as explained by Suryadi [15] are partly "artists" who enter the commercial recording industry. Among them are Sawir Sutan Mudo or also known as Mak Sawir. Mak Sawir was a drummer (speaker of the saluang dendang or bagurau oral tradition) born in 1942. Mak Sawir not only appeared directly in front of a lover's audience but also filled the Dendang program at RRI Bukittinggi every Sunday night. Mak Sawir's proficiency in creating rhymes (songs) dendang also brought Mak Sawir into the recording industry since the 1970s. According to Ediwar's record [16], more than 100 saluang dendang tape tapes were circulating in the community. Likewise, the classic all-around VCD presented by Mak Sawir, including "Tangih Kaki Limo", "Ratok Balingka", and "Siriah Langkok". 
Mak Sawir is one of the speakers of the oral tradition that is consistent with the tradition. Mak Sawir was able to improvise with the pantun he delivered according to the conditions and demands of the audience. But the tradition is still chosen by Mak Sawir while many forms have been created with pop music, dangdut, or even remix have emerged.

When Mak Sawir was consistently on the track, young speakers were sprung up. Among them, Uria Novita, who is currently a student at one of the Arts Institute, appeared as a drummer through the YouTube and Instagram applications. Uria Novita pretty much uploaded a video of her song in the application. One of them was kicked off, insinuating the following @minanglipp Instagram account admin.

\author{
Hari nan sadang da pukua limo \\ Iyo hari nan sadang da pukua limo \\ Kok banyak bana oi pitih da lip \\ Kok tak babini apo gunonyo \\ Kok tak babini apo gunonyo
}

This upload has more than 18,000 views. Uria Novita itself with an@urianovita Instagram account that has 48 thousand followers. While the YouTube account is followed by 3000 followers.

Speakers of other oral traditions who also use contemporary applications and keep up with the development of the internet era are Jon Cakra. Jon Cakra is a salawat artisan (speaker of the salawat dulang tradition) who also released several hilarious Minang albums. With an Instagram@jhoncakra.sabanamanggalitiak account, Jon Cakra publishes his daily activities and also art. Meanwhile, Raja Record's YouTube account was used as a means of publishing his albums, whether they were Minang Kocak songs or salawat dulang albums. Followers for this Jon Cakra Instagram account and YouTube account have also exceeded 3000.

It's different from Jon Cakra on his Instagram account with the number of posts 281. Of all the posts, the tradition of salawat dulang was not displayed and appeared by Jon Cakra besides the documentation of the show in several places. Likewise with youtube accounts that publish more albums. Likewise with the Mak Katik Instagram account which has 310 posts. These posts are general documentation of activities and activities to various places and also meet with many figures. Even so, Mak Katik has 18 posts on his pantun text.

Speaking of the two speakers mentioned above is actually talking about the younger generation who have adapted to the current technological developments. It is rather difficult to find senior speakers who are able to follow this internet era. Even so, Musra Dahrizal is one of those found suits. With a more popular vocation, Mak Katik, he is a speaker of oral traditions who has quite a lot of expertise. Katik Mak is adept at dancing, pasambahan, bagurau, also silek. His knowledge is also very broad, so he is often invited to give custom lectures or even give lectures to students at several universities. Interestingly, Mak Katik, who is currently 69 years old, is able to keep up with the development of internet technology. Mak Katik has a Facebook account and Instagram. Through the application, Mak Katik uploads pantun or rhymes. In this case, Mak Katik uses the media to introduce poetry and his skill. Especially for YouTube, until now Mak Katik does not have its own account. But the art activities and also the Mak Katik custom lectures are pretty much shared on youtube by various accounts. The uploads were also quite popular is " Mak Katik Salingka Nagari Basamo Niniak Mamak 7 Suduik Nagari Sungai Rumbai" by Bhinneka Pro. It's seen 27,272 times within 4 months of uploading. 
In the industrial era 4.0, cassettes and CDs were being abandoned. The public's attention began to be diverted to the internet. Through the internet, various forms of entertainment can be obtained by the community. Here is also a challenge that must be faced by speakers of oral tradition. Speakers of oral tradition are the determinants of bringing oral traditions among the entertainment choices that appear on the internet. One of them was carried out by Uria Novita, who made bagurau appear more contemporary. Of the 90 posts on his Instagram account, 28 is a video of the song poetry. Although brief, the bagurau tradition, in this case, appears in the form of new packaging, namely on social media. But for youtube accounts, Uria Novita only has 11 posts and no one single post that specifically displays the tradition of Bagurau.

It's different from Jon Cakra on his Instagram account with the number of posts 281. Of all the posts, the tradition of salawat dulang was not displayed and appeared by Jon Cakra besides the documentation of the show in several places. Likewise with youtube accounts that publish more albums. Likewise with the Mak Katik Instagram account which has 310 posts. These posts are general documentation of activities and activities to various places and also meet with many figures. Even so, Mak Katik has 18 posts on his pantun text.

Based on these data, oral traditions have not yet become interesting content to be displayed and created on social media by two of the three speakers. While one speaker, Uria Novita, has proven that the bagurau tradition content that he displays has been able to attract the attention of other social media users. This can be seen from the number of followers on Instagram, the number of comments that appreciate their uploads, and the advertisements they get. This means that in addition to lifting the bagurau tradition to be enjoyed in the form of new packaging, the content is also a financial source for Uria Novita. This success is also in line with Min Xu's explanation of the opportunities and challenges that must be faced by society in the era of industrial revolution 4.0.

The presence of social media basically has made many changes in various aspects of people's lives. Among them is the ease of obtaining information and communicating without being blocked by time and place [17]. The research of Siti Ezaleila Mustafa [18] was explained that the use of social media, especially in Indonesia is to watch videos, share photos, and interact between users, and display new innovations. This was also done by speakers of oral traditions in Minangkabau. But innovations related to oral traditions have not been popular.

In the era of the cassette and VCD recording industry, Suryadi [19] explained that several genres of oral tradition had adapted and adapted to these developments [20]. Therefore in the market, we can find forms of tapes and commercial VCDs of oral traditions in Minangkabau. The community accepts these changes and becomes part of its consumers. But in today's internet and multimedia era, Minangkabau oral traditions have not been highlighted to compete with other entertainment. On social media specifically, the Minangkabau oral tradition has not been considered as interesting content or profitable for creation

\section{CONCLUSIONS}

The Minangkabau oral tradition has passed through the era of the recording industry and made it through it. This can be seen from the appearance of cassettes and commercial VCDs of several genres of Minangkabau oral tradition. Entering the era of industrial revolution 4.0 which was marked by the use of the internet and its supporting applications for various activities, the Minangkabau oral tradition again tried to survive. Speakers of the oral tradition have also adapted themselves through the use of social media accounts that are currently popular. 
Based on the research that has been done, the social media used by speakers of the Minangkabau oral tradition is used for several things. First is as a means of self-existence. Various activations and daily activities are published on social media. Including art activities that they do. But specifically, their skill on oral traditions have not been the content uploaded and published. Only one account has shown that oral traditions can be used as interesting content, attracting more followers. It also eventually became a source of income through advertising.

Strengthening and inheritance of oral traditions can basically be done through social media which is currently popular. Likewise, the utilization of other digital technology developments is ongoing. It has been proven in several countries through several studies on the use of digital technology for the sustainability of the tradition. On the contrary, both in Indonesia and Minangkabau in particular, the development of digital technology has not been fully utilized. As a result, the current development is still considered as one of the factors that cause the loss of oral traditions from the community.

\section{REFERENCES}

[1] E. Djamaris, Pengantar Sastra Rakyat Minangkabau. Jakarta: Yayasan Obor, 2002.

[2] D. Amir, Adriyetti., Pemetaan Sastra Lisan Minangkabau. Padang: Andalas University Press, 2006.

[3] W. J. Ong, Orality \& Literacy, The Technological of The Word. New York: Routledge, 1982.

[4] H. Suwardana, "Revolusi Industri 4 . 0 Berbasis Revolusi Mental," Jati Unik, vol. 1, no. 2, pp. 102-110, 2017.

[5] M. Xu, J. M. David, and S. H. Kim, "The Fourth Industrial Revolution: Opportunities and Challenges," Int. J. Financ. Res., vol. 9, no. 2, pp. 90-95, 2018.

[6] T. Dorji, "Preserving our Folktales, Myths and Legends in the Digital Era," J. Bhutan Stud., no. 2002, pp. 93-108, 2002.

[7] S. O. S. Y. Idris, Muhammad Zaffwan, Norsimaa Binti MMustaffa, "Preservation of Intangible Cultural Heritage Using Advance Digital Technology: Issues and Challenges," Harmon. J. Arts Res. Educ., vol. 16, no. 1, pp. 1-13, 2016.

[8] M. I. Z. and A. A. R. Abidin, "Malay Digital Folklore: Using Multimedia to Educate Children Through Storytelling," Inf. Technol. Child. Educ. Annu., pp. 29-44, 2003.

[9] L. Maitra, "Children's oral literature and modern mass media in India with special reference to gradual transformation in West Bengal," Indian Folk. Res. J., vol. 5, no. 8, pp. 55-64, 2008.

[10] N. Anoegrajekti, "Sastra Lokal dan Industri Kreatif: Revitalisasi Sastra dan Budaya Using," ATAVISME, vol. 16, no. 2, pp. 183-193, 2013.

[11] A. B. Lord, The Singer of Tales, Second. Cambridge, Massachusetts London, England: Harvard University Press, 2000.

[12] A. Amir, Sastra Lisan Indonesia. Yogyakarta: Penerbit ANDI, 2013.

[13] Pudentia, Ed., Metodologi Kajian Tradisi Lisan. Jakarta: Asosiasi Tradisi Lisan, 2008.

[14] E. dan Y. S. P. Meigalia, "Model Pewarisan Sastra Lisan Salawat Dulang," in Khazanah Melayu Serumpun dalam Era Baharu, 2018, pp. 282-290.

[15] Suryadi, "The Recording Industry and Regional Culture in Indonesia; The Case of Minangkabau," Universiteit Leiden, 2014.

[16] E. Chaniago, "Seniman Tradisi yang Langka," infokarawitanisipadangpanjang.blogspot.com, 2011. . 
[17] A. S. Cahyono, "Pengaruh Media Sosial Terhadap Perubahan Sosial Masyarakat di Indonesia," Publiaciana, vol. 9, no. 1, pp. 140-157, 2016.

[18] E. Mustafa, "M edia S osial di M alaysia dan Indonesia : Penggunaaannya sebagai Alat Komunikasi , Kolaborasi dan Jaringan Digital," J. Pengaj. Media Malaysia, vol. 15, no. 2, 2013.

[19] Suryadi, "The Impact of the West Sumatran Regional Recording Industry on Minangkabau Oral Literature," Wacana, vol. 12, no. 1, pp. 1-30, 2010.

[20] B.W. Setyawan and K. Saddhono, "Eret traditional ceremony as representation of spirit of mutual cooperation among coastal communities". Adv. Sci. Let. vol. 23 no.10, pp 9991-9992, 2017 